\title{
THE 1964 INTERNATIONAL STOKE MANDEVILLE GAMES FOR THE PARALYSED IN TOKYO
}

\author{
By L. Guttmann, C.B.E., M.D., F.R.C.P., F.R.C.S.
}

THE opportunity to hold a second 1964 Scientific Meeting of the Society was afforded by the International Stoke Mandeville Games for the Paralysed which took place in Tokyo from the 8th to I2th November, following the Olympic Games, when doctors and surgeons interested in the problem of paraplegia were congregated there with their teams.

In the following, a brief report on this unique sports movement is given, which may be of interest to the readers of this journal from both the medical and the humanitarian point of view.

Three hundred and seventy paralysed sportsmen and sportswomen representing 22 countries from all corners of the globe converged upon the capital of Japan during the first week of November for their own version of the Olympic Games. They came from Argentine, Australia, Austria, Belgium, Ceylon, Fiji, France, Germany, Great Britain, Ireland, Israel, Italy, Japan, Malta, the Netherlands, the Philippines, Rhodesia, South Africa, Sweden, Switzerland, U.S.A., and Mexico as observers. Of these Ceylon, Fiji and the Philippines were taking part for the first time.

These Games, which were started in the first place by the author as a national event in 1948 at Stoke Mandeville Hospital in the town of Aylesbury in England, became in 1952 the first international disabled sports event in the world. From year to year, the number of sports events and competitors have increased, and this organised activity of adapted wheelchair sport has brought to the world's attention the ability of disabled people, even with a handicap of such magnitude as paraplegia, to become sportsmen and sportswomen in their own right. Sport-originally introduced at Stoke Mandeville in 1944 as remedial exercises complementary to the conventional methods of physiotherapy-has proved to be an ideal natural outlet for the paraplegic's energy and recreation, and it plays today an important part in his social integration. In I960, these Games were held for the first time outside Great Britain, namely in Rome, organised by Dr. A. Maglio and the I.N.A.I.L. following the regular Olympic Games and under Olympic Games' conditions. The great success of these Games encouraged the International Stoke Mandeville Games Committee to hold the Games every four years, if possible, in the same venue as that of the Olympic Games.

\section{MEDICAL ASPECTS}

For many years, paraplegics have, therefore, been travelling long distances to compete in their own sports meetings. This involves, of course, a number of medical aspects, some of which may be mentioned briefly here.

Firstly, it has been proved that paraplegics can tolerate long-distance flights subject to change of altitude. In none of the long journeys travelled by air-and these include a trip made by teams from Great Britain, Rhodesia and Singapore to Perth, Western Australia, for the First British Commonwealth Paraplegic Games 
in 1962 organised by Dr. G. Bedbrook-has there been any instance of any illeffects, apart from the odd case of air sickness (which was not confined to the paraplegics!). The second aspect has been the question of oedema of the legs. We have made studies during our flight to and from Australia by comparing the measurements of the legs and feet of the paraplegics as well as the able-bodied passengers. While swelling occurred in paraplegics, it could not be said that those with lesions above $\mathrm{T}_{5}$ suffered any more than those with lesions below $\mathrm{T}_{5}$. Moreover, there was also no significant difference in the swelling of the legs of the paraplegics as compared with those of the able-bodied passengers. In all cases, the swelling gradually disappeared at varying rates after landing.

The urinary question did not create any particular problem. Patients with cauda equina lesions who were able to walk went, of course, to the toilet. For the others, urinals were emptied by the escorts at regular intervals. The female paraplegics had their pads changed by the nursing staff at regular intervals during the flight. Those who required bowel evacuation were transported to the toilet in narrow wheelchairs specially built by the air lines concerned to pass up and down the gangway of the plane. By a strict preparatory régime, there were no accidents with regard to the bowels.

An important point is the problem of acclimatisation, whether at places en route - for instance, in the Far East-or at the place of destination. No adverse effects in this respect were observed, but it must be remembered that so far there have never been extremes of climate and altitude at the place of destination. Although the British team arrived in Western Australia's 'summer' straight from a British winter, no difference was found as Australia had a freak cold spell at the time, which made the British feel at home, while the Australians were shivering! However, this was no doubt fortunate, as only a week later the temperature rose to very high degrees and many of the able-bodied participants in the British Empire and Commonwealth Games suffered great discomfort from the heat, including heat-stroke. The climate in Tokyo was usually pleasantly warm during the day but definitely colder in the early morning and evening, and was well tolerated by all from whatever continent or country they had come.

One readily realises that even for the able-bodied a 22-hour trip from Europe to Tokyo, which involves having one's day and night rhythm completely disorganised, is quite an ordeal. Therefore, one could expect that for a paraplegic or tetraplegic such an upheaval would be especially tiring and difficult. And, yet, unlike their fellow athletes of the Olympic Games, who had many days for acclimatisation and adjustment, our paralysed competitors had to commence their Games within 36 hours of arrival in Tokyo. Moreover, through certain circumstances beyond our control, the sports events had to be cramped into the space of four and a half days. The paraplegic sportsmen and sportswomen proved their fitness and adaptability by undergoing this physical and mental strain with no ill-effects. Moreover, incredible as it may seem, despite the strain imposed by the long journey and the shortness of time at their disposal, standards in some sports events were even higher, and indeed several records were broken. This applies in particular to field events and swimming. In this respect, the author was interested to hear from a medical member of the International Olympic Committee that they have found that their sportsmen must start immediately on arrival or after an interval of at least ro days to overcome the negative phase of acclimatisation.

There were no serious incidents during the Games. The only cases worth 
mentioning are (I) a pulmonary infection in a tetraplegic, which, however, was successfully dealt with in the Village, and (2) a British girl who had the misfortune to break her ankle when getting from the toilet on to the wheelchair in her bungalow, just before the Games started. This was put into plaster, and although missing the field events she entered one of the three-day archery competitions with her leg in plaster, and won a silver medal! The Japanese Organising Committee had arranged a 24-hour medical service, which was excellent and with which the medical officers of the various teams were in close contact.

As one who, for many years, has recognised the profound physical and mental capabilities of the well-rehabilitated spinal paraplegic, the author together with his colleagues has nevertheless been profoundly impressed by the extraordinary toughness and resilience of the competitors. Within the space of two weeks, many of them had travelled 20,000 miles or more, had had their whole day and night rhythms changed not only on the outward journey but also, of course, on the return home, had taken part in strenuous sports competitions, joined in all the social activities, including sight-seeing trips, and had to be ready to return to work within a day or two of arriving back home. This is certainly a revolutionary change in the old concept of paraplegia!

\section{ACCOMMODATION IN THE OLYMPIC VILLAGE}

The various teams were accommodated in bungalows in the Olympic Village, while most of the escorts were housed in two-storey buildings. The Village was formerly an American Army base with married quarters. To facilitate entry into the bungalows, special ramps had been erected and the doorways to bathrooms and toilets widened to allow easy access for wheelchairs. Long ramps had also been erected leading to the dining-rooms, and these were guarded by young Japanese Self-Defence Force members, who were ready and eager at all times to give a helping hand to the wheelchair athletes.

There was a post office, bank, shop, and international club in the Village, all of which were readily accessible to wheelchairs. This in itself demonstrates the great pains taken by the Japanese organisers to make the paraplegic entirely independent.

A special catering service was organised under the management of a University Professor, and many students, both male and female, served at the tables on a purely voluntary basis. Both western and Asian style dishes were available, with an exaggerated version of an English breakfast being served every day, consisting of bacon and three fried eggs!

We were immensely struck by the eagerness and devotion of the huge band of volunteers-many of them young University students-who gave their services day and night. Included among these were young interpreters who were attached to each house throughout the whole games. These young people were mainly organised by the Japanese Junior Red Cross Society, under the leadership of Mrs. Hashimoto. A volunteer car service was organised by private citizens, who were available with their cars at any time of the day or night to transport paraplegics and and escorts to any destination in Tokyo.

\section{EVENTS}

The following sports events were included in the games: archery, dartchery (a combination of darts and archery), basketball, fencing, field events (javelin distance 
and precision, shot put, discus, and club-throwing), snooker, swimming, table tennis, weight lifting, wheelchair races, and wheelchair slalom.

The opening ceremony of the Games took place in a huge sportsfield in splendid sunshine and was a most spectacular affair. The teams of the various nations took part in a Wheel-Past. The Patrons of the Games-the Crown Prince of Japan and Princess Michiko-opened the Games, which were also attended by many officials of the Government and Metropolis of Tokyo, amongst them $\mathrm{Mr}$. Kanda, Minister of Health and Welfare, and the Governor of Tokyo Metropolis, Professor Azuma (a former Professor of Pharmacology at the University of Tokyo) as well as representatives of the various Embassies. The closing ceremony was held in the great indoor gymnasium, again under the patronage of the Crown Prince and Princess. The arena, which seated about 5000 people, was filled to capacity and many people were standing. Both ceremonies were most moving events, and to hear the huge crowd joining in the singing of Auld Lang Syne at the closing ceremony was an unforgettable experience.

It was estimated that about I00,000 spectators visited the Games.

\section{DEEPER SIGNIFICANCE OF THE GAMES- IMPACT ON THE JAPANESE PUBLIC}

Although the will to win was very high and each wheelchair athlete gave of his best, running through the whole Games was a sense of deeper purpose which binds the paraplegics into a close unity, for they realise that the Games have a much deeper significance than the winning of medals and honours for their country, and at all times they were true to the three ideals of the Stoke Mandeville Games: FRIENDSHIP, UNITY AND SPORTSMANSHIP.

Perhaps the most lasting impression of these Games will be the great friendship which sprang up between the Japanese people and the visitors from overseas. Competitors and escorts settled down to live in the Village in great harmony, and the hospitality of the Japanese people, who showered the teams daily with gifts, was quite overwhelming. There is no doubt that the Games made a dramatic impact on the Japanese public, which was awakened to the urgent need for improving their facilities for the disabled to enable them to live lives as respected citizens within the community. Although a good deal has definitely been achieved in improving services for the disabled in Japan, much is still to be done. From our experience of the desire on the part of the Japanese public to give their services to their disabled fellow-men, starting from the top with the Imperial Family, Government and Municipal authorities, and the understanding shown by the many members of the public for the aims of the Stoke Mandeville Games for the paralysed, there is great hope that they will give full and active support to any plans to help their disabled fellow-men regain their rightful dignity as workers and sportsmen. This conviction is strengthened by the report the author has just received to the effect that the Ministry of Labour in Japan has decided to start a factory for paraplegics, which he understands will be opened in July this year.

Finally, it can be said that the great success of the Tokyo Paraplegic Games was possible only by the splendid co-operation of the Japanese Government, the Governor of Tokyo Metropolis and, in particular, the Japanese Organising Committee under the leadership of Mr. Y. Kasai, and the International Stoke Mandeville Games Committee. 